\title{
Aposporic development of gametophyte in Sematophyllum subpinnatum (Brid.) E. Britton (Sematophyllaceae) from capsule wall
}

\author{
Meenu Mathew, Abraham Mathew ${ }^{*} \&$ Sindu N \\ P.G. and Research Department of Botany, St. Peter's College, Kolenchery, 682 311, Kerala, India
}

^Email: abrphyton@gmail.com

OPEN ACCESS

\section{ARTICLE HISTORY}

Received: 08 August 2021

Accepted: 27 November 2021

Available online

Version 1.0: 01 January 2022

\section{Check for updates}

\section{Additional information}

Peer review: Publisher thanks Sectional Editor and the other anonymous reviewers for their contribution to the peer review of this work.

Reprints \& permissions information is available at https://horizonepublishing.com/ journals/index.php/PST/open_access_policy

Publisher's Note: Horizon e-Publishing Group remains neutral with regard to jurisdictional claims in published maps and institutional affiliations.

Indexing: Plant Science Today, published by Horizon e-Publishing Group, is covered by Scopus, Web of Science, BIOSIS Previews, Clarivate Analytics, etc. See https:// horizonepublishing.com/journals/index.php/ PST/indexing_abstracting

Copyright: $\odot$ The Author(s). This is an openaccess article distributed under the terms of the Creative Commons Attribution License, which permits unrestricted use, distribution and reproduction in any medium, provided the original author and source are credited (https://creativecommons.org/licenses/ by/4.0/)

\section{CITE THIS ARTICLE}

Mathew M, Mathew A, Sindu N. Aposporic development of gametophyte in Sematophyllum subpinnatum (Brid.) E. Britton

(Sematophyllaceae) from capsule wall. Plant Science Today. 2022;9(1):48-51. https:// doi.org/10.14719/pst.1433

\begin{abstract}
In the present study, an axenic culture of Sematophyllum subpinnatum (Brid.) E. Britton was attempted from spores. However, spores failed to germinate, but protonemata were seen arising from the diploid capsule wall cells by apospory. Few cells of the capsule wall turned green, and the protoplast divided, resulting in the extension of the protoplast as a germ tube, which developed into protonemata. Protonemata were less spreading, and adult gametophytes developed from these protonemata. The aposporic plants so developed were transferred to soil, and they showed normal growth but with decreased branching. No sex organs and sporophytes were seen. This is the first report of aposporic development of S. subpinnatum from the capsule wall.
\end{abstract}

\section{Keywords}

moss, sodium hypochlorite, sporophyte, protonema, MS media

\section{Introduction}

Bryophytes are the first group of plants to colonise a terrestrial habitat and are the second largest group of terrestrial plants next to angiosperms. Axenic culture of bryophytes is devised as an easy way of obtaining the required biomass for bioprospecting studies. It is a method of raising a single species of plant devoid any contaminating microbes. This reduces the exploitation of species and also ensures aseptic biomass. Several authors have developed a wide array of protocols for raising axenic cultures of bryophytes. Of these, spore as a source of inoculum is the simplest method as it is easy to surface sterilise without affecting the protoplasm (1).

Axenic culture from spores was reported in mosses such as Entosthodon hungaricus (Boros) Loeske (1), Hyophila nymaniana (M. Fleisch.) M. Menzel (2), Philonotis falcata (Hook.) Mitt. (3), Pogonatum urnigerum (Hedw.) P. Beauv. (4), Philonotis thwaitesii Mitt., Brachythecium plumosum (Hedw.) Schimp. (5) and Bryum argentum Hedw. (6). Ripe capsules are generally used for sterilising as the capsule wall protects the enclosed spores from the harmful effect of the sterilant used. The capsule wall has thickening that could withstand the harsh sterilisation process. However, there are no reports as to aposporic development from the capsule wall.

Sematophyllum subpinnatum (Brid.) E. Britton is a common lignicolous moss, cosmopolitan in distribution with a creeping stem $(2.5-4.5 \mathrm{~cm}$ long) with irregular pinnate branching. Leaves are ovate, acuminate and faintly toothed at the apex with swollen alar cells. Costa absent, cells faintly 
papillose at the apex. Alar cells are seen as two distinct rows, the lower row with oblong cells and the upper row with short cells. Sporophytes are seen on the main stem or branches, with erect seta and inclined to pendant capsules. There are few reports on the economic importance of Sematophyllum. Sematophyllum adnatum is used by Mexican tribes for the preparation of medicinal tea (7). S. subhumile is sensitive to $\mathrm{SO}_{2}(8)$. Sematophyllum is a potential biomonitor of atmospheric metal deposition. It can accumulate $\mathrm{Zn}$ and $\mathrm{Pb}$ at high concentrations (9). Hence, micropropagation of this species and introducing it in localities with $\mathrm{Zn}$ and $\mathrm{Pb}$ can help reduce the harmful effects caused due to these pollutants in the environment.

The present study describes the aposporic development of the gametophyte of S. subpinnatum from the capsule wall.

\section{Materials and Methods}

\section{Plant Collection}

Plants with sporophytes were collected in sterile bottles from the evergreen forest of the Kulamavu area $\left(9.7920^{\circ} \mathrm{N}\right.$, $76.8865^{\circ} \mathrm{E}$ ) in the Idukki District of Kerala, India and brought to the laboratory for identification and axenic culture. Identification was made following relevant literature (10). The voucher specimen is deposited as herbarium (SPC B-12) in the Department of Botany, St. Peter's College, Kolenchery.

\section{Initiation of axenic culture}

$15 \mathrm{ml}$ half-strength MS medium devoid of sugar ( $\mathrm{pH}$ 6.0) and $1 \%$ agar was poured into $50 \mathrm{ml}$ test tubes to solidify. The mouth of the tubes was plugged using non-absorbent cotton and autoclaved (Labline, AV 101) at $15 \mathrm{lb}$ pressure for $20 \mathrm{~min}$ and made as slants. The un-dehisced capsule was surface sterilised using $0.5-1.0 \%$ sodium hypochlorite for 5-10 min. It was washed well with double distilled water and using a sterile micropipette tip the capsule was crushed to release spores. The spores, along with capsule debris, were inoculated onto MS agar slants. The inoculated tubes were kept under $16 \mathrm{hr}$ light and $8 \mathrm{hr}$ dark cycle at $25^{\circ} \mathrm{C}$ for two months.

\section{Culturing of axenic plant in soil}

To observe the growth pattern, the axenic plant was cultured in glass bottles. Borosil glass bottles were half-filled with a moist potting mixture consisting of soil, sand and coir pith in the ratio $1: 1: 1$. It was autoclaved four times at $15 \mathrm{lb}$ pressure for $20 \mathrm{~min}$ to make it aseptic. The axenic plants were placed aseptically in the soil, and the glass bottle was sealed with a cap and was left undisturbed with $16 \mathrm{hr}$ light, $8 \mathrm{hr}$ dark cycle at $25^{\circ} \mathrm{C}$ for 4 months. As a control, natural haploid gametophores were also grown in glass bottles under similar conditions.

\section{Results and Discussion}

After three weeks of incubation, green protonema growth was seen. A lower sterilant concentration with a lower treatment time $(0.5 \%$ sterilant for $5 \mathrm{~min})$ was ineffective in removing contaminants (Table 1 ). Contamination percentage became zero with $1.0 \%$ sterilant treatment for $10 \mathrm{~min}$.

Table 1. Effect of sterilant concentration and time of treatment for development of protonema

\begin{tabular}{ccccc}
\hline $\begin{array}{c}\text { Experi- } \\
\text { ment }\end{array}$ & $\begin{array}{c}\text { Conc. of } \\
\text { Sterilant }\end{array}$ & $\begin{array}{c}\text { Treatment } \\
\text { time }\end{array}$ & Contamination \% $\begin{array}{c}\text { Tubes showing } \\
\text { axenic protonemal } \\
\text { growth (\%) }\end{array}$ \\
\hline E1 & $0.5 \%$ & $5 \mathrm{~min}$. & 100 & 0 \\
E2 & $0.5 \%$ & $10 \mathrm{~min}$. & 17 & 83 \\
E3 & $0.75 \%$ & $5 \mathrm{~min}$. & 50 & 50 \\
E4 & $0.75 \%$ & $10 \mathrm{~min}$. & 17 & 67 \\
E5 & $1.0 \%$ & $5 \mathrm{~min}$. & 17 & 50 \\
E6 & $1.0 \%$ & $10 \mathrm{~min}$. & 0 & 17 \\
\hline
\end{tabular}

Nevertheless, out of the six tubes, only in one, there was protonemal growth. Compared to higher sterilant concentration, treatment with $0.5 \%$ sterilant for 10 min could reduce contamination, and five tubes showed axenic protonemal growth. Thus, the protocol developed from this study is to surface sterilise the capsule with $0.5 \%$ sodium hypochlorite for $10 \mathrm{~min}$.

Visible protonemal growth was seen after six weeks of inoculation, but on examination, protonema was seen arising from the capsule wall. None of the spores produced protonema. Capsule wall cells that were brown turned green after 21 days of inoculation (Fig. 1a). On average, 36 $\%$ of the capsule wall cells turned green after 21 days of inoculation. The protoplasm rounded off, divided and thereafter protruded out of the cell (Fig. 1b). Later, the protrusion underwent divisions to form filamentous protonema (Fig. 1c, 1d). The protonemata were short and branched, and after eight weeks of incubation, produced 15-20 gametophores. The gametophores were slender and creeping (Fig. 1e), with rhizoids arising adventitiously from the stem (Fig. 1f). On inoculation to the soil, protonemata proliferated and spread towards the glass container wall, and gametophores were seen emerging from these protonemata (Fig. 1g). On culturing axenic plants in garden soil, aposporic gametophores showed reduced growth compared to haploid gametophores under similar conditions (Fig. 1h). No sporophyte was seen even after six months of culture in soil.

Apospory in bryophytes was discovered by Pringsheim by observing the development of gametophytic structures from the sporophytic tissues of moss plants without the involvement of spores (11). Apospory and apogamy have been progressively displaced with the perfection of the sexual cycle that gave selective advantage due to variations created by meiosis. However, in mosses, gametophytic and sporophytic phases can readily be made unstable in appropriate experimental conditions (12). It was observed that the isolated protoplast from sporophyte of Funaria hygrometrica Hedw. on culturing, gametophytic plant was developed (13). Reports are on aposporic gametophyte development from the setae of the liverwort Blasia pusilla L. after 3 to 6 weeks of incubation in sugar-free media (14). Mature thalli developed within 2-3 months in glucose nutrient agar when sterile apices were transferred. Archegonial development was seen, but not 


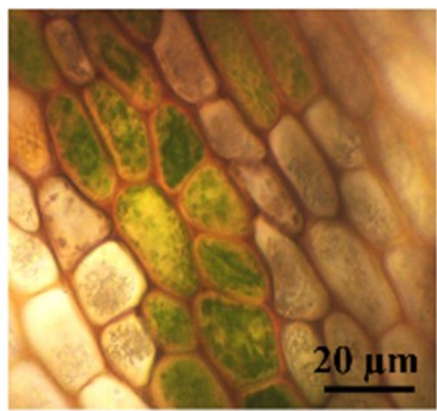

A

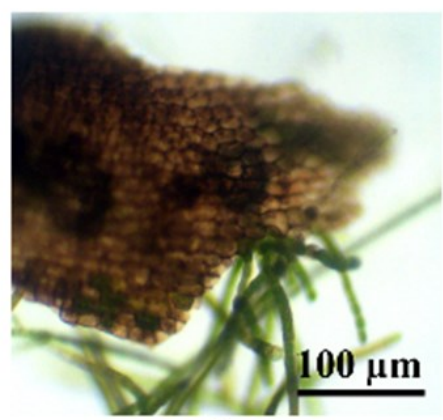

C.

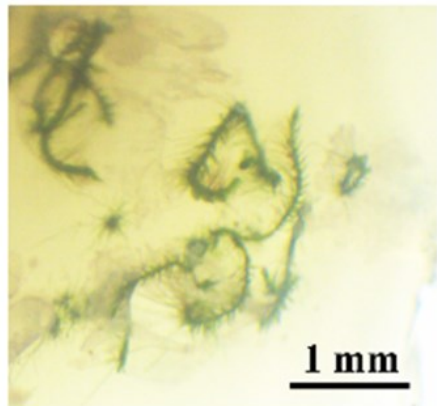

E

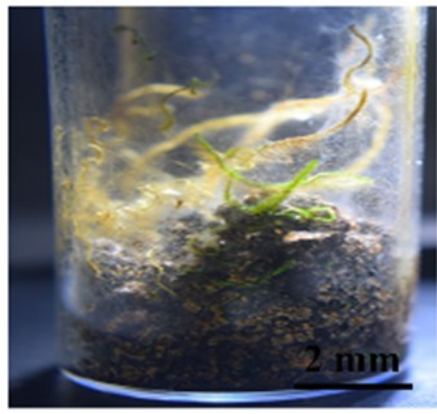

G
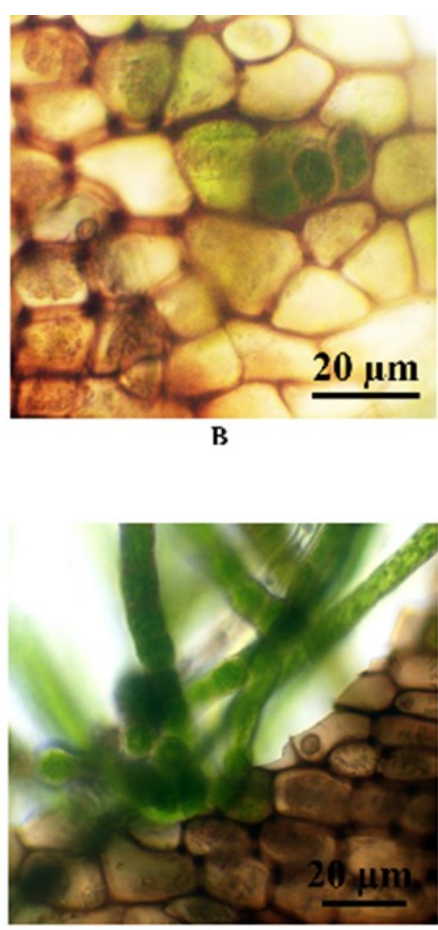

D
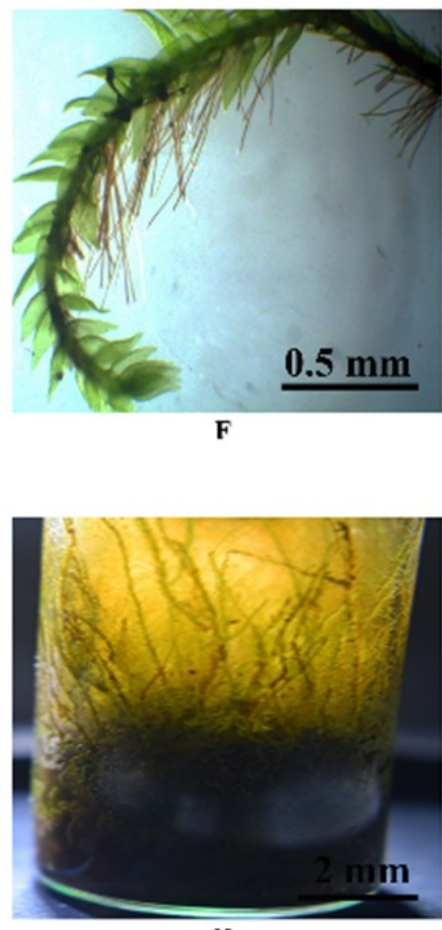

H

Fig. 1. Development of protonema and gametophyte from capsule wall.

A. Greening of capsule wall B. Initiation of protonema C. Protonema from capsule wall D. Protonemal branching E. Axenic development of gametophyte F. Adult gametophyte $\mathbf{G}$. Aposporic gametophyte in soil $\mathbf{H}$. Haploid gametophyte in soil.

antheridia. The Growth-rate and branching of aposporic hanced the axenic development of protonemata, thereby gametophytes of $B$. pusilla were similar to that of haploid offering a novel protocol in the study of moss axenic culplants. However, in the present study, aposporic plants ture. Aposporic protonema was induced from capsule wall, were less vigorous than the normal haploid plants. The spo- from which adult diploid gametophyte arose.

rophyte of mosses have limited growth and short lived. This may be the reason for lower vigour in aposporic plant.

\section{Conclusion}

\section{Acknowledgements}

Meenu Mathew is thankful to the Council of Scientific and Industrial Research (CSIR) for providing a Junior Research The present study brings to light that surface sterilisation of Fellowship (JRF) to carry out her doctoral studies. Authors the capsule with $0.5 \%$ sodium hypochlorite for 10 min en- are thankful to the Department of Science and Technology 
(DST) for the Fund for Improvement of Science and Tech- 5. nology (FIST), Government of India, for the grant in Aid for creating facilities for research.

\section{Authors contributions}

MM carried out the collection of the specimen, axenic culture, analysis and drafting of the manuscript. AM accompanied MM during the collection and took microphotographs. SN designed the study. All authors read and approved the final manuscript.

\section{Compliance with ethical standards}

Conflict of interest: Authors do not have any conflict of interests to declare.

Ethical issues: None.

\section{References}

1. Sabovljevic MS, Papp B, Sabovljevic A, Vujicic M, Szurdoki E, Segarra-moragues JG. In vitro micropropagation of rare and endangered moss Entosthodon hungaricus (Funariaceae). Biosci J. 2012;28(4):632-40.

2. Mishra R, Pandey VK, Chandra R. In vitro culture of the moss Hyophilla nymaniana (Fleish.) Menzel and its phytochemical screening. Int J Phytomedicine. 2014;6(3):377-83.

3. Nisha KK, Apsara IG, Rejitha RF, Antony A, Saranya AS, Chandran SA, Swathy RU. In vitro culture of Philonotis falcata (Hook.) Mitt., A moss species from Nilgiri hills. Trends in Biosciences. 2018;11 (7):1310-13.

4. Cvetic T, Sabovljevic A, Sabovljevic M, Grubisic D. Development of the moss Pogonatum urnigerum (Hedw.) P. Beauv. under in vitro culture conditions. Arch Biol Sci. 2007;59(1):57-61. https:// doi.org/10.6165/tai.2012.57(1).27.10.2298/ABS0701057C.
Awasthi V, Nath V, Pande N, Asthana AK. Morphogenetic studies and in vitro propagation of two mosses: Philonotis thwaitesii Mitt. and Brachythecium plumosum (Hedw.) B.S.G. Taiwania. 2012;57 (1):27-36. https://doi.org/10.6165/tai.2012.57(1).27.

6. Sabovljevic M, Bijelovic A, Dragicevic I. Effective and easy way of establishing in vitro culture of mosses, Bryum argentum Hedw. and Bryum capillare Hedw. (Bryaceae). Arch Biol Sci. 2002;54(12):7-8. https://doi.org/10.2298/ABS0202001S.

7. Glime JM. Medical Uses: Medical Conditions. In: Glime JM (ed) Bryophyte Ecology, 5th edition. Michigan Technological University and the International Association of Bryologists. 2017;p. 5-6.

8. Taoda H. Mapping of the atmospheric pollution in Tokyo based upon epiphytic bryophytes. Jap J Ecol. 1972;22:125-33.

9. Mazzoni AC, Lanzer R, Bordin J, Schafer A, Wasum R. Mosses as indicators of atmospheric metal deposition in an industrial area of southern Brazil. Acta Bot Brasilica. 2012;26(3):553-58. https:// doi.org/10.1590/S0102-33062012000300005.

10. Daniels AED, Sreebha R, Kariyappa KC. Bryoflora of Indira Gandhi National Park in Anamalai Hills, India. Dehra Dun: Bishen Singh Mahendra Pal Singh. 2018; p. 278-82.

11. Bryan VS. Apospory in mosses discovered by Nathanael Pringsheim in a brilliant epoch of botany. The Bryologist. 2001;104 (1):40-46. $\quad$ https://doi.org/10.1639/0007-2745(2001)104 [0040:AIMDBN]2.0.CO;2

12. Bell PR. Apospory and apogamy: implications for understanding the plant life cycle. Int J Plant Sci. 1992;153(3):123-36. https:// doi.org/10.1086/297070

13. Binding H, Mordhorst G. Gametophyte regeneration and apospory from archegoniate protoplasts under conditions devised for higher plants. Bot Acta. 1991;104:330-35. https:// doi.org/10.1111/j.1438-8677.1991.tb00238.x

14. Matkze EB, Raudzens L. Aposporous diploid gametophytes from sporophytes of the liverwort Blasia pusilla L. Proceedings of the National Academy of Sciences of the United States of America. 1968;59(3):752-55. https://doi.org/10.1073/pnas.59.3.752

$\S \S \S$ 